http://dx.doi.org/10.18778/7969-455-6.03

Jerzy Z. Pająk

Kielce

\title{
POLACY W GALICJI WOBEC AUSTRO- -WĘGIER W LATACH I WOJNY ŚWIATOWEJ
}

\section{Przed 1914 rokiem}

Proces kształtowania świadomości narodowej społeczności mieszkających w Galicji był specyficzny, co wynikało z przynależności do wielonarodowego i wielowyznaniowego imperium habsburskiego. W ciągu ponad stuletniej historii zaboru austriackiego wykształcił się na jego terenie, szczególnie $\mathrm{w}$ okresie autonomicznym, typ polityka i działacza, łączącego własne poczucie narodowe ze specyficznym patriotyzmem austro-węgierskim. To o nich pisał w 1912 Wilhelm Feldman, „mija 140 lat od czasu przyłączenia Galicji do Austrii. Smutne przypomnienie - tym smutniejsze, ze w przededniu tej „rocznicy” padły słowa o „moralnym podboju", dokonanym na nas przez Austrię i że każdy dzień przynosi tego podboju realne dowody. Myślimy kategoriami Galicji i Lodomerii, kategoriami prowincji austriackiej, straciliśmy zupełnie perspektywy i związki duchowe z całością Polski" ${ }^{1}$. W ogromnej masie postawę tę reprezentowali, urzędnicy administracji państwowej i autonomicznej. Ludzie ci, na ogół podzielający poglądy polityczne rządzących konserwatystów i demokratów stanowili właściwą i wpływową grupę, na której opierały się rządy habsburskie. Galicyjski korpus urzędniczy, dobrze wykształcony, z dużym bagażem doświadczenia, cieszył się w społeczeństwie poważaniem. Starostowie, którzy wielokrotnie sprawowali funkcje przez wiele lat, znakomicie znali teren oraz stosunki, i potrafili jak dowodzą tego liczne przykłady wpływać na kierowane przez siebie społeczności w kierunku pożądanym przez władze w Wiedniu i we Lwowie.

1 W. Feldman, Polityka galicyjska czy polska, „Krytyka” 1912 (lipiec-sierpień), t. 3, s. 1. 
Podstawowe grupy ludności, akceptowały istniejący system rządów, a tym samym przynależność do Austro-Węgier. Sprzyjały temu stosunkowo większe niż w innych dzielnicach Polski swobody polityczne, a zwłaszcza rozwój parlamentaryzmu. Powoływanie Sejmu Krajowego na podstawie niedemokratycznej ordynacji kurialnej, przy zacofaniu społeczno-gospodarczym Galicji, pozwalało konserwatystom, akcentujących swój lojalizm wobec zaborcy odgrywać zasadniczą rolę w życiu politycznym. Postawa ta nie budziła w przededniu wojny ostrych sprzeciwów, co wynikało z jednej strony z liberalnej polityki monarchii habsburskiej, z drugiej zaś - ze zbliżania się wojny z Rosją. Również powstałe na przełomie wieków nowoczesne ruchy polityczne: narodowi demokraci, socjaliści i ludowcy mogli dzięki istniejącym swobodom politycznym poszerzać znacząco zasięg swoich wpływów. Udział ich przedstawicieli w pracach Sejmu Krajowego i parlamentu w Wiedniu stwarzał im dodatkowe możliwości prezentowania swoich poglądów. Wybory, szczególnie od 1907 r. do parlamentu wiedeńskiego sprzyjały poszerzaniu bazy społecznej tych partii. To wszystko sprzyjało akceptowaniu istniejącego porządku politycznego.

Postulaty własnej niepodległości państwowej głoszone przez irredentystów większość społeczeństwa polskiego uważała raczej za marzenie niż za realny program polityczny. Nie była odosobnioną opinia przywódcy galicyjskich ludowców Wincentego Witosa, który charakteryzując rządy austriackie przed 1914 rokiem stwierdził:

administracja była dość sprawna i przeważnie bezstronna. Sądy spełniały swoje czynności prawie bez zarzutu. Prawa obywatelskie były szanowane, samorządy uznawane. Mimo, że wielu urzędników pozwalało sobie na publiczną krytykę rządu - nikt nie pociągał ich za to do odpowiedzialności, nie szykanował, nie niszczył, a nawet nie przenosił. Szlachcie działo się zupełnie dobrze, mieszczaństwo również nie miało powodu by narzekać. Chłopi płacili stosunkowo niskie podatki gruntowe, dostawali zapomogi na wypadek szkód i klęsk elementarnych. Dość poważne subwencje na różne cele udzielane przez rząd nie były wcale rzadkością. Sejm i Wydział Krajowy, od szeregu lat pracowały wiele i z dużym pożytkiem dla kraju. Budowało się drogi, prowadziło melioracje, regulowało rzeki, zakładało szkoły².

Jak wynika z powyższego proces asymilacji państwowej zaszedł przed $1914 \mathrm{r}$. w zaborze austriackim znacznie dalej niż w innych ${ }^{3}$.

2 W. Witos, Moje wspomnienia, opr. E. Karczewski, R. J. Szaflik, Warszawa 1988, s. 356.

3 Stąd znacznie później, w konfrontacją z realiami II Rzeczypospolitej powstał mit o szczęśliwej Galicji rządzonej przez sprawiedliwego cesarza, zob. R. Hołda, "Dobry" władca. Studium antropologiczne o Franciszku Józefie I, Katowice 2008.; E. Wiegendt, Austria Felix, czyli o micie Galicji w polskiej prozie współczesnej, Poznań 1997; A. Wodan, Mit Austrii w literaturze polskiej, Kraków 2002; A. Kożuchowski, Pośmiertne dzieje Austro-Węgier. Obraz monarchii habsburskiej w piśmiennictwie międzywojennym, Warszawa 2009. 
Problematyką podjęta przeze mnie $\mathrm{w}$ tym artykule zajmowali się już historycy, by wymienić teksty Grzegorza Markiewicza ${ }^{4}$, Piotra Szlanty ${ }^{5}$, Damiana Szymczaka ${ }^{6}$. Stosunek Polaków wobec monarchii habsburskiej ewoluował w latach I wojny światowej - stąd spróbuję w prezentowanym tekście zasygnalizować główne etapy tego procesu.

\section{Po wybuchu wojny}

Większość społeczeństwa jak i elit politycznych zaboru austriackiego witała wybuch wojny z obawą o dalszy los. Wypowiedzenie wojny Serbii 28 lipca 1914 a następnie osiem dni później z Rosją oraz zarządzenia mobilizacyjne władz austriackich wyrywające $z$ dotychczasowego życia tysiące ludzi, przekonywały najdobitniej o nieuchronności przyszłych wydarzeń. Jak pisała Zofia Romanowiczówna „Stało się! padły kości - od 3 dni wojna - prócz Austrii z Serbia, wojna Niemiec z Rosją i Francją - powszechna mobilizacja - prócz tamtych mobilizują prawie wszystkie państwa europejskie, a nasi są we wszystkich szeregach. Straszne! ...Co będzie, co będzie?... Może kataklizm, a może odrodzenie na nowe piękniejsze życie... (...) Tu od trzech dni ruch ogromny - biorą rekrutów, powołują rezerwę, biorą konie, wywożą amunicję - ci, co idą do boju, w jakiejś części idą z zapałem, z nadzieją, inni z rezygnacja, wielu z rozpaczą. Nie mogę patrzeć na te długie szeregi ludzi pędzonych na rzeź"7.

Zdecydowana większość mieszkańców Galicji w tym okresie manifestowała postawy lojalizmu i swoistego austro-węgierskiego patriotyzmu, o czym świadczył m.in. sprawny i bezkonfliktowy przebieg mobilizacji ${ }^{8}$.

${ }^{4}$ G. Markiewicz, Świadomość państwowa społeczeństwa polskiego okresu zaborów. Stan badań, postulaty badawcze, w: Lata Wielkiej Wojny. Dojrzewanie do niepodległości 1914-1918, red. D. Grinberg, J. Snopko, G. Zackiewicz, Białystok 2007, s. 27-28.

${ }^{5}$ P. Szlanta, "Najgorsze bestie to sq Honwedy”. Ewolucja stosunku polskich mieszkańców Galicji do monarchii habsburskiej podczas pierwszej wojny światowej, w: „Spotkania Galicyjskie 2011" Warszawa 2011, s. 161-179.

${ }^{6}$ D. Szymczak, Między Habsburgami a Hohenzollernami. Rywalizacja niemiecko-austro-węgierska w okresie I wojny światowej a odbudowa państwa polskiego, Kraków 2009; tegoż, Między Habsburgami a Hohenzollernami. Dynastie państw zaborczych w oczach społeczeństwa polskiego podczas I wojny światowej, w: „Studia Historica Slavo Germanica”, t. XXVII, 20062007, Poznań 2008, s. 217-234.

7 Z. Romanowiczówna, Dziennik lwowski 1842-1930, t. 2 (1888-1930), Warszawa 2005, s. 251.

8 Przykładowo „Głos Rzeszowski” donosił „mobilizacja w Rzeszowie poszła energicznie i gładko. Obliczano z góry, ile trzeba będzie żandarmów do sprowadzania opornych, a po ogłoszeniu mobilizacji brakuje żandarmów, by wstrzymywali ogromny nacisk zgłaszających się do wojska przed drzwiami biur wojskowych. Notujemy te autentyczne 
Wedle Wincentego Witosa „,z chwilą wybuchu i rozpoczęcia wojny ogromna większość ludności polskiej w Galicji stała bezwzględnie po stronie państwa austriackiego (...) Wszyscy zresztą byli przekonani, że przy obecnej technice wojna będzie trwała najwyżej parę miesięcy, nie każdy tam zginie, ale wszyscy zarobia, bo zwykle po wojnach tak bywało (...) Żołnierz nie pytał się wcale, po co ta wojna, jakie ma cele, jakie może mieć skutki i następstwa. Jego czas przyszedł, on przysięgał cesarzowi i on musi tej przysięgi dotrzymać. Wzywa go zaś nie kto inny, ale sam cesarz, to idzie, żeby spełnić przysięgę i być wiernym do końca «na lądzie i morzu» (...) Do szeregów szło wszystko ochotnie jak na wesele. Wielu zgłaszało się takich, co mobilizacją wcale nie byli objęci ${ }^{9}$. Stanisław Srokowski uważał podobnie: Wszyscy wierzyli święcie, że wojna będzie zaczepna, że niema najmniejszej obawy wtargnięcia Rosjan, że wojsko austriackie jest liczne i doborowe. Zwyczajny tok zajęć ogółu ludności, toż samo i urzędów nie uległ żadnemu wypaczeniu. Poza tym ogólny brak orientacji wśród społeczeństwa polskiego był tak kompletny, że przeważnie nikt nie myślał ruszać w czymkolwiek własnym konceptem. (...) Mobilizacja szła krokiem równym i pewnym, a coraz to nowe oddziały wojskowe opuszczały miasto, niektóre wspaniale przyodziane w nowiutkie mundury, a wszystkie z muzyką i wśród radosnych okrzyków gromadzącej się na ulicach publiczności, zwłaszcza zaś żydostwa"10.

Na ulicach galicyjskich miast dochodziło w tym czasie do pochodów i demonstracji, podczas których obok austriackich powiewały flagi biało-czerwone i żółto-niebieskie, zaś orkiestry obok austriackich grały polskie i ukraińskie pieśni patriotyczne. Manifestacje te odbywały się od 30 lipca do końca sierpnia. Do największych doszło we Lwowie i Krakowie. Według Józefa Białyni-Chołodeckiego: „wydany przez Koło Polskie «Manifest do narodu polskiego», wzywający rodaków do czynu, (...) i donoszący o zgodzie cesarza Franciszka Józefa I na ujęcie polskiej siły zbrojnej narodowej w zbrojne Legiony pod polską komenda (...), obudził niewymowną wdzięczność w sercach Lwowian, jaka znalazła dobitny wyraz w niezwykle uroczystym obchodzie, dnia 18 sierpnia, osiemdziesiątej czwartej rocznicy urodzin władcy dzielnic Habsburgów. (...) O godzinie

obawy i rezultat na wieczną rzeczy pamiątkę. Naród kwapi się... i wszystkie nadzieje pokłada w austriackim Cesarzu”. Wojna, „Głos Rzeszowski” nr 26, 9 VIII 1914, s. 1.

9 W. Witos, Moje wspomnienia..., s. 357.

10 S. Srokowski, Z dni zawieruchy dziejowej 1914-1918, Kraków 1933, s. 7-8, Podobnie opisują te dni inni obserwatorzy: A. Krasicki, Dziennik z kampanii rosyjskiej 1914-1916, Warszawa 1988, s, 25; W. Kossak, Wspomnienia, Warszawa 1973, s. 280 czy Krakowie J. Dąbrowski, Dziennik 1914-1918, Kraków 1977, s. 33-34; M. Lityński, Z dni grozy i walki o wolność 1914-1915, Lwów 1928, s. 48; K. Srokowski NKN. Zarys historii Naczelnego Komitetu Narodowego, Kraków 1923, s. 82-83. 
8 wieczorem, zaroiły się ulice śródmieścia kilkunastotysięcznymi tłumami publiczności. Nieobecne we Lwowie muzyki pułkowe zastąpiła, przed głównym odwachem muzyka kolejowa z pochodniami i lampionami, która po odegraniu hymnu ludowego, podążyła w pochodzie pod Namiestnictwo, Komendę Korpusu, stamtąd zaś pod pomnik Mickiewicza. Tutaj na stopniach pomnika odegrała ponownie hymn ludowy, następnie „Pieśń Legionów Dąbrowskiego”. Publiczność wznosiła podczas tego, co chwila okrzyk "Niech żyje cesarz", "niech żyje Austria”, "niech żyje Polska", „,niech żyje armia"11.

Do wspierania monarchii habsburskiej wzywały instytucje autonomiczne i samorządowe, jak np. Sejm Krajowy czy rady miejskie Krakowa i Lwowa. Rada miasta Lwowa w swej odezwie stwierdzała: „jesteśmy najlepszymi obywatelami tej monarchii, w której znaleźliśmy najsilniejszą ostoję i uznanie naszych praw. Gdy więc teraz ta monarchia znalazła się $\mathrm{w}$ niebezpieczeństwie, jesteśmy gotowi do wszystkich ofiar krwi i mienia w obronie jej całości. Obowiązek nasz spełnimy chętnie i mężnie..."12 W podobnym duchu wypowiedziało się także Koło Polskie w Wiedniu ${ }^{13}$. W atmosferze nastrojów antyrosyjskich i prohabsburskich powstaje 16 sierpnia 1914 wspólna reprezentacja polityczna Polaków galicyjskich - Naczelny Komitet Narodowy w którego skład weszły wszystkie liczące się stronnictwa polityczne. NKN opowiedział się za rozwiązaniem sprawy polskiej w oparciu o Austrię i powołał do życia Legiony Polskie mające u boku armii austro-węgierskiej walczyć z Rosją ${ }^{14}$. Powstanie krakowskiego komitetu zostało przyjęte przez polską społeczność Galicji przyjęte entuzjastycznie. Jak pisał świadek tych wydarzeń: „gdy zjednoczenie stronnictw na podstawie aktu z dnia 16 sierpnia 1914 nastąpiło, nastrój powiatu stał się wybitnie narodowy, jednolity, absolutnie dynastyczny dla Habsburgów. Można powiedzieć, iż w tym czasie miało miejsce zastosowanie w praktyce słów Stanisława Tarnowskiego «przy Tobie stoimy, zawsze z Austrią». Jeden i ten nastrój panował na wsi, we dworze, w mieście"15.

11 J. Białynia-Chołodecki, Lwów w czasie okupacji rosyjskiej (3 września 1914-22 czerwca 1915), Z własnych przeżyć i spostrzeżeń, Lwów 1930, s. 24-25; na temat ówczesnych manifestacji donosiła także szeroko ówczesna prasa zob. m.in. Manifestacje wojenne, "Czas” 1914, nr 309 z 30 lipca, s. 1; Manifestacje, "Gazeta Lwowska” 1914, nr 173 z 1 sierpnia, s. 2.

12 Manifestacja Rady Miejskiej, „Kurier Lwowski” 1914, nr s. 328 z 1 sierpnia, s. 3; H. Kramarz, Samorząd Lwowa w czasie pierwszej wojny światowej i jego rola w życiu miasta, Kraków 1994, s. 29.

13 Koło polskie a wojna, "Czas” 1914, nr 316 z 3 sierpnia, s. 1.

14 Szerzej na ten temat: W. Suleja, Orientacja autro-polska w latach I wojny światowej (do aktu 5 listopada 1916 roku), Wrocław 1992, s. 36-42, zob. też K. Srokowski NKN. Zarys historii..., s. 23-28.

15 Odpowiedź na kwestionariusz DW NKN, Oświęcim 18 VI 1915, ANKr, Arch. NKN, t. 281, k. $76-77$. 
Tymczasem wydarzenia na froncie nie potwierdziły żywionych przez większość Galicjan nadziei na szybkie zwycięstwo nad Rosją. Po wybuchu wojny do 19 sierpnia grupa gen. Kümmera ścierając się z oddziałami rosyjskiej 14 dywizji kawalerii gen. Nowikowa zajęła obszar od Kielc do Sandomierza. W tym czasie 1 i 4 Armia austro-węgierska kończąc pomyślnie koncentrację podjęły ofensywę na Lublin i Chełm. Opór stawiły im rosyjskie 4 i 5 Armia. Tak doszło w końcu sierpnia do dwóch bardzo krwawych a wygranych przez Austro-Węgry bitew pod Komarowem i Kraśnikiem. Początkowe sukcesy wojsk austro-węgierskich w Królestwie Polskim zostały jednak szybko zniwelowane przez podjętą 26 sierpnia przez Rosjan ofensywę siłami dwóch armii 3 i 8 na wschodnim odcinku frontu. Po bitwach pod Złoczowem, i Gniłą Lipą Rosjanie przełamali front i zmusili broniącą Lwowa 3 armię austro-węgierską do oddania miasta oraz odstąpienia na linię rzeki Wereszczycy. Kontrofensywa dokonana w październiku 1914 przez wojska państw centralnych, mimo chwilowych sukcesów w postaci odblokowania Przemyśla i podejścia pod Warszawę okazała się jednak chwilowym sukcesem i do połowy listopada utracono te zdobycze i linia frontu powróciła na linię Dunajca i łuku Karpat. W początkach grudnia 1914 rozpoczęła się bitwa o Kraków i walki w rejonie Limanowej. Dopiero tutaj udało się zatrzymać atakującą armię rosyjską i po wielkich krwawych walkach odblokować Kraków i odzyskać z początkiem stycznia linię rzeki Dunajec. W ten sposób większość Galicji znalazła się pod okupacją rosyjską ${ }^{16}$.

Po pierwszych klęskach wojsk austro-węgierskich, rozpoczęły się represje ze strony armii. Ułatwiały je wprowadzone rozkazem Naczelnego Wodza z 3 sierpnia 1914 sądy doraźne. Sądziły one osoby wojskowe i cywilne znajdujące się $\mathrm{w}$ obrębie działania armii $\mathrm{w}$ polu ${ }^{17}$. Cofające się pobite oddziały austriackie zauważały wszędzie nieprzychylne nastawienie

${ }^{16} \mathrm{Na}$ temat działań militarnych piszą m.in. J. Bator, Wojna galicyjska. Działania armii austro-węgierskiej na froncie pótnocnym (galicyjskim) w latach 1914-1915, Kraków 2005, s. 29-139; J. Dąbrowski, Wielka Wojna 1914-1918, Warszawa 1937; M. Klimecki, Operacje wojenne na ziemiach polskich w latach 1914-1915, w: U źródeł niepodległości 1914-1918. Z dziejów polskiego czynu zbrojnego, pod red. P. Staweckiego, Warszawa 1988, s. 85-124; J. Pajewski, Pierwsza wojna światowa 1914-1918, Warszawa 2004; M. Zgórniak, 1914-1918. Studia i szkice z dziejów I wojny światowej, Kraków 1987; Österreich-Ungars Letzter Krieg, red. E. Glaise-Horstenau, Wien 1930; Der Krieg 1914-1917 im Wort und Bild, red. A. Ardenne, Berlin-Leipzing-Wien-Stuttgart 1917; А. М. Зайончковский, Мировая война 1914-1918 г2., т. 1-3, Москва $1938-39$.

17 Res 44. Rozkaz Naczelnej Komendy Armii o wprowadzeniu sądów doraźnych w strefie dziatań wojennych, 3 VIII 1914, Biblioteka Centralnego Dzierżawnego Istorycznego Archiwum Ukrainy we Lwowie (dalej CDIAUL), Kolekcja afiszy i odezw, spr. 7243, k. 3 L.18.668/pr. Obwieszczenie, Lwów 8 VIII 1914, ibidem, k. 1. 
ludności, szpiegostwo oraz zdradę na rzecz Rosjan. Jak zapisała Matylda Sapieżyna „pod tym względem prawdziwa psychoza ogarnęła wielu członków armii, na każdym kroku węszono zdrady i szpiegostwo, i choć bez kwestii było dosyć wypadków zdrady i szpiegostwa, zapewne najczęściej chwytano niewinnych. Wystarczył ogień rozpalony na polu, garnek lub bielizna rozwieszona na żerdziach płotu, chłop zagadnięty znienacka, dający mylną odpowiedź, co do drogi na prawo lub lewo - to już posądzenie o zmowę z nieprzyjacielem!"'18 Szczególnie brutalnie zachowywały się oddziały węgierskie, które nie mogąc się porozumieć z miejscową ludnością, starały się siłą wymusić posłuch.

Jak twierdził Zygmunt Lasocki „nie tylko psychoza wojenna uciekających żołnierzy, lecz także i chciwość była powodem tworzenia się plotek o zdradach. Mordowano ludzi jako zdrajców, by zagrabić ich mienie. Mordowano także mężów broniących żon, ojców córek, przed zgwałceniem. Zapewne i chęć wykazania się szczególnymi zasługami i uzyskania nagród lub awansu, skłaniała żołnierzy do wyszukiwania domniemanych szpiegów i zdrajców. Wielu ludzi niewinnych padło ofiarą samosądów wojskowych"19. Zdarzało się także, że aresztowano chłopów, pod zarzutem zdrady, a następnie po zapłaceniu przez nich okupu, wypuszczano ich na wolność. Władze zachęcały do denuncjowania szpiegów, których widziano głównie wśród Rusinów oskarżanych o moskalofilstwo. Nie może, więc dziwić, że w wielu przypadkach wystarczył donos nieżyczliwych sąsiadów, aby zostać zatrzymanym. Do końca września 1914 roku liczba aresztowanych pod zarzutem zdrady wzrosła do ponad 10000 ludzi. Wszystkie te osoby po krótkim pobycie w więzieniach we Lwowie i Krakowie specjalnymi pociągami wywieziono w głąb cesarstwa. Większość z nich internowano w specjalnie zbudowanym obozie w Thalerhoff koło Grazu, zaś część konfirmowano w Styrii i Austriii ${ }^{20}$.

Wojskowi austriaccy reagowali histerycznie na wszelkie przejawy krytyki swoich poczynań. W powiecie bocheńskim, gdy jedna z chłopek Katarzyna Zacharowa, z Krzeczowa publicznie stwierdziła: „Moskale to mają siłę wielka, a Austriacy to dziady", sąd polowy w Bochni skazał ją za to na śmierć przez powieszenie. Tylko dzięki interwencji miejscowych notabli u dowódcy 1 armii złagodzono jej wyrok ${ }^{21}$. To przeczulenie wojskowych

${ }_{18}$ M. z Windisch-Graetzów Sapieźyna, My i nasze Siedliska, Kraków 2003, s. 236.

19 Z. Lasocki, Polacy w austriackich obozach dla uchodźców i internowanych (wspomnienia z czasów wojny światowej byłego posła do parlamentu austriackiego), Kraków 1929, s. 74,

${ }^{20} \mathrm{Na}$ temat represji po wybuchu wojny J. Z. Pająk, Od autonomii do niepodległości. Kształtowanie się postaw politycznych i narodowych społeczeństwa Galicji w warunkach wielkiej wojny 1914-1918, Kielce 2012, s. 81-88.

21 Wieś galicyjska (referat z Bochni i Brzeska), 25 II 1915, Archiwum Narodowe w Krakowie (dalej ANKr), Archiwum Naczelnego Komitetu Narodowego (dalej Arch. 
i poszukiwanie przez nich zdrady szczególnie nasiliło się pod koniec 1914 roku, gdy z trudnością udało się odeprzeć rosyjską ofensywę na Kraków. Operujące w powiecie brzeskim oddziały niemieckie, postępowały brutalnie w stosunku do wysiedlanych chłopów z wiosek nad Dunajcem. Gdy doprowadzeni do rozpaczy ludzie zaczęli protestować - Niemcy powiesili dla postrachu kilku chłopów oraz wzięli zakładników ${ }^{22}$.

Wszystko to budziło nastroje niechętne, w niektórych przypadkach wręcz wrogie do ustępującej armii i administracji austro-węgierskiej. Tym bardziej, że nawet w ocenie emisariuszy NKN o wiele lepiej zachowywały się $\mathrm{w}$ tym czasie nacierające oddziały rosyjskie. Przykładowo w powiecie brzeskim "głównie niemal wyłącznie skarżono się na niszczycielskie instynkty honwedów, których stawiano niżej kozaków ze względu na ich nawyczki rabunkowe...", zaś w powiecie bocheńskim chłopi opowiadali emisariuszom, że "po ustąpieniu Moskali, mimo ich grabieży byśmy wyżyli jako tako. Aż tu nadciągnęli Węgrzy i Prusacy i rekwirują w sposób bezwzględny wszystko, trudno się z nimi porozumieć. A u Moskali to płaczem matki i dzieci, często dało się to i owo od łupiestwa uratować" ${ }^{23}$. Jednocześnie upadał autorytet władz cywilnych, poprzez $\mathrm{z}$ jednej strony brak skutecznej obrony cywili u władz wojskowych, z drugiej zaś pospieszną ucieczkę przedstawicieli tych władz przed wkraczającymi Rosjanami ${ }^{24}$.

Mimo wszystko zdecydowana większość mieszkańców Galicji jak wcześniej powiedziano manifestowała postawy lojalizmu wobec armii i monarchii austro-węgierskiej, uważając je za swoją armię i swoje państwo. Pomagano powszechnie żołnierzom, którzy np. w wyniku działań wojennych znaleźli się poza linią frontu. Przykładem tego może być wypadek ukrywania przez miejscowych chłopów ze wsi Zawadka w powiecie nowosądeckim oddziału honwedów. Nie był to rzecz odosobniona, $\mathrm{w}$ tym samym powiecie chłopi ukrywali żołnierzy austriackich m.in. w Białej Wodzie, Charzenicach ${ }^{25}$. W innych powiatach, np. w kolbuszowskim, miejscowi chłopi, pomagali żołnierzom z pułków tyrolskich, którzy ukrywali się w Puszczy Sandomierskiej, skąd prowadzili działania partyzanckie przeciwko oddziałom rosyjskim ${ }^{26}$.

NKN), t. 281, k. 390.

22 Raport Władysława Stylińskiego, II 1915, ibidem, k. 378,

${ }^{23}$ Wieś galicyjska (referat z Bochni i Brzeska), 25 II 1915, ibidem, k. 390.

${ }^{24}$ Raport generalny z podróży okrężnej w powiatach Galicji zachodniej, odbytej w dniach 10-25 stycznia 1915, ibidem, t. 281, k. 385.

${ }^{25}$ Relacja z powiatu nowosądeckiego, I 1915, ibidem, t. 279, k. 16-18.

26 J. Hupka, Z czasów wielkiej wojny. Pamiętnik nie kombatanta, Lwów 1937, s. 95-96. 


\section{Okupacja rosyjska Galicji}

Okres okupacji rosyjskiej Galicji stanowił ogromny wstrząs dla jej społeczeństwa. Obalony został w tym czasie porządek rzeczy, który od ponad stu lat wydawał się niewzruszony i stały. Nowi władcy kraju realizując swoje długofalowe plany polityczne których celem była ostateczna inkorporacja wschodniej Galicji do cesarstwa rosyjskiego otrzymali poparcie tej część społeczności ruskiej, która z nimi wiązała swe nadzieje i oczekiwania, a więc obóz staroruski. Zajęcie Galicji miało jednak dla Rosji o wiele większe znaczenie niż proste rozszerzenie swego terytorium. Przed $1914 \mathrm{r}$. z niepokojem śledzono rozszerzanie się wpływów narodowego obozu ukraińskiego, który oddziaływał na tę część Ukrainy, która należała do imperium rosyjskiego. Okupacja Galicji stwarzała więc okazję aby to niebezpieczne dla interesów Rosji ognisko separatyzmu ukraińskiego zlikwidować raz na zawsze. Przybyli dygnitarze rosyjscy, niezależnie od głoszonych oficjalnie deklaracji o poszanowaniu praw tamtejszych mieszkańców, za swój obowiązek uważali wyplenienie „zarazy mazepińskiej”27.

Dla ludności ukraińskiej okupacja rosyjska była katastrofę, niszczącą jej cały wieloletni dorobek w dziedzinie oświaty narodowej, rozpraszający marzenia o Piemoncie galicyjskim, z którego miało powstać niepodległe państwo ukraińskie. Oznaczała zagładę języka, religii unickiej, wszelkich cech odrębności, a także swobód obywatelskich gwarantowanych w monarchii habsburskiej. Zamknięto stowarzyszenia oświatowe i naukowego, ograniczono działalność towarzystw gospodarczych. Używanie języka ukraińskiego w mowie było tolerowane, natomiast cenzura nie pozwalała niczego drukować w ukraińskim języku. Powszechnie niszczono księgozbiory książek ukraińskich, które zabierano z czytelni Tow. „Proświta” a następnie palono. W głąb Rosji wywieziono dziesiątki działaczy ukraińskich, czy to w charakterze zakładników czy to osób deportowanych za nieprawomyślność ${ }^{28}$. Swobodę działania oraz poparcie uzyskali politycy moskalofilscy, którzy od dawna wspierali program inkorporacji wschodniej części kraju do Rosji.

27 Szerzej na temat okupacji rosyjskiej: A. Achmatowicz, Polityka Rosji w kwestii polskiej w pierwszym roku Wielkiej Wojny 1914-1915 Warszawa 2003, s. 348-391; А. Бахтурина, Политика Российской Илперии в Восточной Галиции в годы Первой Мировой войны, Москва 2000; tејżе Окраинь Российской илперии: государственное управление и национальная политика в добъ первой мировой войны (1914-1917 г2.), Москва 2004, Ch. Mick, Kriegserfahrungen in einer multietnischen Stadt: Lemberg 1914-1947, Wiesbaden 2010, s. 111-127; J. Z. Pająk, Od autonomii do niepodległości..., s. 91-127.

28 J. Z. Pająk, Ukraiński ruch narodowy w Galicji w początkach I wojny światowej. (Między idea Wielkiej Rusi a idea niepodległości ukraińskiej), w: Galicja - mozaika nie tylko narodowa, red. U. Jakubowska, Warszawa 2013, s. 27-56. 
Nowe władze rosyjskie, przygotowując przyłączenie wschodniej części kraju do Rosji starały się zarazem ograniczyć siłę żywiołu polskiego na okupowanych terenach. Zamknięto polskie szkoły i uczelnie wyższe. Rozwiązane zostały polskie stowarzyszenia oświatowe i naukowe oraz ograniczono działalność towarzystw gospodarczych. Jednocześnie usunięto język polski z wielu urzędów i sądów. Aresztowano byłych wojskowych narodowości polskiej a także wzięto setki zakładników. Podczas okupacji rosyjskiej najbardziej widoczni stali narodowi demokraci na czele ze Stanisławem Grabskim, którzy byli zwolennikami rozwiązania sprawy polskiej w oparciu o Rosję a więc głosili program zjednoczenia i autonomii ziem polskich w ramach imperium Romanowych i za cenę jego realizacji godzili się na włączenie wschodniej Galicji wraz ze Lwowem bezpośrednio do cesarstwa rosyjskiego ${ }^{29}$.

Pisząc o stosunkach pod okupacją rosyjską nie sposób zauważyć, że władze okupacyjne robiły wszystko, aby ustabilizować nastroje na nowo podbitych terenach. Jak relacjonował Stanisław Krawczyk: „Szeroki ogół ludności starano się sobie pozyskać przez aprowizację. Aprowizowano doskonale, w formie prowiantów: mąki, cukru, herbaty, sucharów, soli itd. Towary dawali wyborowe. Przychodziły od carowej, od miasta Moskwy, od rządu rosyjskiego. Rozdawano bezpłatnie lub po minimalnych cenach, podając źródło skąd pochodzi. Środek okazał się nader skuteczny. Ludność po tej aprowizacji w wielkim stopniu uspokoiła się. Ludność wiejska uboższa i mieszczaństwo mniej zamożne żywo wyrażała swoje zadowolenie. Zdarzały się wypadki, że patrzono z żalem na odwrót wojsk rosyjskich. Ten sposób i rodzaj agitacji udał się Rosji znakomicie" ${ }^{30}$.

W pierwszych miesiącach okupacji odbiór działań władz rosyjskich spotykał się z pozytywnym odzewem wśród niektórych grup ludności, szczególnie wśród chłopów, wśród których pokutował mit, że w bezkresnej Rosji uda się rozwiązać najbardziej palący problem wsi galicyjskiej - problem braku ziemi. Pamiętano także o represjach i postępowaniu władz i armii austro-węgierskiej w pierwszych miesiącach wojny. Postępowanie władz i armii rosyjskiej wydawało się początkowo potwierdzać ten osąd. Emisariusz NKN na powiat kolbuszowski i niski stwierdzał „chłopa hołubiono, obiecywano rozmaite udogodnienia, a że ich nie uskuteczniano, obiecywano dalej zarekwirowane konie i krowy przyprowadzić z Rosji, bo u nich wszystkiego «bohato»"31. Na niektórych terenach,

29 A. Wątor, Narodowa Demokracja w Galicji do 1918 roku, Szczecin 202, s. 315-329; J. Z. Pająk, Od autonomii do niepodległości..., s. 127-136,

30 Odpowiedź na kwestionariusz DW NKN, obejmujacy dane odnoszace się do powiatu jasielskiego, Oświęcim 18 VI 1915, ANKr, Arch. NKN, t. 279, k. 74.

31 Raport z powiatów Nisko i Kolbuszowa, 22 VI 1915, ibidem, t. 281, k. 424. 
jak np. na Łemkowszyźnie, gdzie wcześniej były znaczące wpływu ruchu moskalofilskiego manifestowano otwarcie radość z powodu nadejścia wojsk rosyjskich. O pozytywnym stosunku wobec Rosjan, świadczą także opinie urzędników i wojskowych austriackich ${ }^{32}$.

Ten stosunek do Rosjan zmieniał się w miarę narastania obciążeń na rzecz armii rosyjskiej a także coraz powszechniejszego stosowania przez nich represji wobec szerokich grup społeczeństwa galicyjskiego. Jak pisał kierownik Starostwa w Stryju: „rozkoszy panowania knuta rosyjskiego doświadczyła ludność wiejska przy pędzeniu jej i zmuszaniu do robót przy szańcach i przy różnych rekwizycjach" ${ }^{\prime 33}$. W pierwszej połowie 1915 narastały nastroje proaustriackie i oczekiwanie na wejście wojsk państw centralnych. Jak stwierdzał Henryk Herzig, emisariusz NKN działający we wschodniej Galicji „sami Moskale, (...) byli najlepszymi lekarzami moskalofilstwa tych czy innych lokalnych grup politycznych ludności polskiej”34.

\section{Z powrotem pod władzą Habsburgów}

Wiosna 1915 roku miała decydujące znaczenie dla działań wojennych w Galicji. Rozpoczęcie w końcu marca 1915 przez armię austro-węgierską wspomaganą przez Niemców działań ofensywnych doprowadziło pod koniec sierpnia tegoż roku do odbicia większości okupowanych przez Rosjan terenów galicyjskich. Mimo prób kontratakowania przez poszczególnych dowódców rosyjskich nie przyniosło to żadnych skutków i front w lipcu 1915 ustabilizował się na wschód od stolicy Galicji, na linii rzeki Strypy, gdzie rozpoczęły się długotrwałe walki pozycyjne.

W większości uwalnianych od panowania rosyjskiego miast i miasteczek ludność entuzjastycznie witała żołnierzy armii austro-węgierskiej, a także legionistów polskich i ukraińskich. Gdy „13 grudnia br. [1914] weszła pierwsza patrol austriacka do [Nowego] Sącza ludność nosiła na rękach pierwszych zwiastunów swobody, którymi byli przypadkowo huzarzy węgierscy. Na drugi dzień rano wjechała do miasta kawaleria Legionu. Na widok polskich czapek ułańskich, na widok żołnierzy, którzy przychodzili jako oswobodziciele prawdziwi spod męczącej rosyjskiej zmory, ludność tłumnie na ulicach zebrana rzucała się wzajemnie sobie

${ }^{32}$ Relacja Adama Schwarza dot. zachowania się ludności ruskiej w pow. dolińskim podczas okupacji rosyjskiej, Kraków, 30 marca 1915, CDIAUL, fond (dalej f.) 146, opis (dalej op.) 8, sprawa (dalej spr.) 1891, s. 5.

${ }_{33}$ L. 436 Pismo kierownika starostwa w Stryju (Czepielewskiego) dot. gospodarki rosyjskiej w Stryju i powiecie, Stryj, 18 VI 1915, ibidem, op. 4, spr. 5153, s. 17.

${ }^{34}$ Raport Herziga z powiatu kołomyjskiego, ANKr Arch. NKN, t. 281, k. 90. 
na szyję. Wiele osób płakało ${ }^{35}$. W Tarnowie powitanie wkraczającej naszej armii oraz nadciągających wodzów i ich sztabu, wreszcie samego głównodowodzącego marszałka i towarzyszącego mu następcy tronu odbyło się wśród objawów sympatii i radości przy trzykrotnej iluminacji miasta, które dotychczas jest udekorowane flagami o barwach narodowych, miejskich i państwowych" ${ }^{\prime 36}$. W demonstracjach tych uczestniczyli wszyscy mieszkańcy miast, liczni obserwatorzy zauważali przy tym, że szczególnie mocno wyrażała swoją radość, co zrozumiałe w świetle polityki rosyjskiej społeczność żydowska.

Nastroje radości i ulgi wśród społeczeństwa ze względu na zakończenie okupacji rosyjskiej szybko jednak pod wpływem postępowania zarówno wojsk austro-węgierskich jak i niemieckich zaczęły się zmieniać. Jak pisał emisariusz NKN w powiecie jasielskim „wojska węgierskie zachowywały się względem ludności pod każdym względem nieżyczliwie. Rabunki i kradzieże Węgrów można porównać tylko z rabunkami dzikich dywizji kozackich. Są nieodosobnione przypadki, że właściciele mieszkań w czasie całorocznej inwazji rosyjskiej nie potrzebowali opuszczać swych siedzib, w czasie pobytu Węgrów, zwłaszcza honwedów, obecność ludności we własnym domu czy mieszkaniu stawała się absolutnie niemożliwa. Wpadali jak najdziksze hordy, od razu wszystkim drzwiami oraz oknami, nie była to rekwizycja, ale najpospolitszy rabunek"37.

Wiktor Daniec stwierdzał: „w licznych gminach nie było jednak już, czego szukać, bo jak ludzie mówili «wszystko zabrał huzar, a co nie mógł zabrać to zabrali kozacy». Gdy mieszkańcy narzekali na kozaków i nie przeczyli, że Moskale to są rabusie i złodzieje, ale mówili, że wasi huzarzy są stokroć gorsi. (...) Cała droga, gdzie szli znaczona była pożarami i wiszącymi trupami polskiego ludu, tak, że od widoku oczy odwracać musieli (...) kraj nieprzyjacielski zaczynał się u nich, tam gdzie kończyły się Węgry, a więc już od grzbietu Karpat, gdzie bestialska natura tego narodu wyszła jaskrawo na wierzch, na wieczną narodu tego hańbę. Kamienie i drzewa płaczą w Galicji tam którędy szli Węgrzy. W Galicji były wsie, gdzie wszystkie kobiet gwałcili, następnie wieś otaczali, a kto się życie ratując wychylił strzelali - dziecko czy starzec, kobieta czy mężczyzna. Hunowie w pierwotnej postaci" ${ }^{38}$.

35 Moskale w Nowym Sączu (garść szczegółów), XII 1914, ibidem, t. 279, k. 228.

36 Sprawozdanie z pobytu nieprzyjaciela w Tarnowie od 10 XI 1914 do 5 VI 1915, ibidem, t. 281, k. 300.

37 Odpowiedź na kwestionariusz DW NKN, obejmujący dane odnoszące się do powiatu jasielskiego, 28 VI 1915, ANKr Arch. NKN, t. 281, k. 77.

38 Sprawozdanie Wincentego Dańca, powiatowego komisarza wojskowego w Rzeszowie, Rzeszów 8 VI 1915, ibidem, k. 238. 
Niewiele czasu było potrzebne, aby większość społeczeństwa zdała sobie sprawę z tego, że ta powracająca władza austriacka, nie jest już taka, jaką była przed wojną. Całość spraw administracyjnych nad odzyskiwaną prowincją dostała się w ręce wojskowych. Po odwołaniu pod koniec lipca 1915 Witolda Korytowskiego nowym namiestnikiem został generał Hermann von Colard ${ }^{39}$. Mimo protestów Polaków, również następni namiestnicy nominowani przez cesarza do końca rządów austriackich zarówno Erich von Diller jak i Karl Huyn byli zawodowymi wojskowymi. Należy podkreślić, że wszyscy ci Namiestnicy mianowani w czasie wojny byli podporządkowani zarówno rządowi centralnemu w Wiedniu jak AOK w Cieszynie. Ta podwójna zależność utrzymała się do końca rządów austriackich Rządy wojskowych namiestników wiązały się z napływem do administracji cywilnej oficerów zarówno służby czynnej jak i emerytowanych. Byli to najczęściej Niemcy i Czesi nieprzygotowani do pełnionych funkcji. Jak twierdził 25 X 1917 w swym przemówieniu w parlamencie austriackim poseł Alfred Halban „obsadzono starostwa oficerami. Czy otrzymali oni dyspensę od przepisanych studiów? Komu podlegają oni pod względem dyscyplinarnym? Odebrano ich wojsku, nie należą jednak do etatu urzędników. Dokąd więc należą? Znaleźli się także nagle oficerowie $\mathrm{w}$ dyrekcji policji we Lwowie, by wypełnić luki powstałe przez powołanie urzędników policyjnych do wojska. Więc urzędnicy $\mathrm{w}$ wojsku, a oficerowie na urzędach" ${ }^{\prime 4}$. Ponieważ owi wojskowi nie znali języka polskiego, wobec tego w urzędowaniu administracji państwowej coraz częściej używano języka niemieckiego ${ }^{41}$. Dla Polaków, którzy od 50 lat niemal niepodzielnie sprawowali rządy $\mathrm{w}$ tej autonomicznej prowincji stanowiło to trudne i nieoczekiwane doświadczenie. Jak pisał w kwietniu 1916 Jan Hupka, „Austriaków jakiś zły duch opętał. Rozmaitym cywilnym i wojskowym dygnitarzom przypomniały się czasy absolutyzmu. Parlamentu ani sejmów nie ma. Sędziwy cesarz odcięty od wszystkiego. Przed nikim teraz nie są odpowiedzialni, więc związali się w klikę, której nie chodzi ani o dynastię, ani o państwo, tylko o własne egoistyczne interesy, o drugie i trzecie rentowne posady przy wojennych etatystycznych przedsiębiorstwach, o mniej lub więcej legalne zyski pieniężne i wpływy. Mając nieograniczoną władzę, używają sobie jak chciwi, źli, zawistni szaleńcy i głupcy. (...) Rząd cywilny niema żadnej prawie władzy. Rządzi Austria

39 Szerzej na temat okoliczności odwołania W. Korytowskiego P. Szlanta, „Najgorsze bestie to sa Honwedy"..., s. 167-168.

40 Ein Reden der Abgeordnete Halban, In: Stenographisches Protokoll Haus der Abgeordneten XXII Session (30.05.1917-12.11.1918), 34. Sitzung, s. 1170.

${ }^{41} \mathrm{O}$ administracji w tym okresie J. Z. Pająk, Od autonomii do niepodległości..., s. 158167. 
o ile to rządami nazwać można Cieszyn - to jest klika czeskich i niemieckich pułkowników" ${ }^{\prime 2}$.

Na obszarze wschodnim kraju właściwe rządy sprawowała niemal do końca wojny Komenda Etapów 2 armii, której podlegali także starostowie podporządkowani nadal Namiestnictwu. Służba etapowa starała się zapewnić jak największe wykorzystanie gospodarcze terenów znajdujących się obszarze operacji wojennych. Jej zadaniem był dowóz potrzebnych surowców i materiałów, ewakuacja ludności cywilnej, budowa i konserwacja sieci kolejowej, drogowej i telefonicznej, zapewnienie bezpieczeństwa, zarządzanie służbą sanitarną a także administrowanie tym obszarem. $Z$ istotnym dla mieszkańców przepisów utrudniających im życie były bardzo ostre rygory w zakresie przemieszczania się i podróżowania szczególnie na ścisłym obszarze wojennym. Utrudniało to odbudowę gospodarczą i powrót do normalnego życia. Inną cechą rządów wojskowych było wykorzystywanie przez nich instytucji komisarzy rządowych. Budziło to liczne protesty, bowiem komisarze rządowi dysponowali majątkiem kierowanych przez nich wspólnot samorządowych. Odbyty 25 XI 1917 r. zjazd delegatów miast wzywał „rząd, by dla ochrony interesów szerokich warstw ludności jak najrychlej przywrócił samorząd w tych miastach, które obecnie pozostają pod zarządem komisarzy rządowych" ${ }^{\prime 3}$.

Usuwając ślady rosyjskiego panowania w kraju, Austriacy skierowali ostrze swych represji przeciwko ludności ruskiej postrzeganej przez nich z powodu zachowania się działaczy moskalofilskich podczas okupacji jako niepewny politycznie element,. Pod hasłem walki z „ruską zdradą” rozpętała się druga fala prześladowań. Rozpoczęły się masowe egzekucje rzeczywistych i domniemanych sympatyków Rosjan. Około 30000 ludzi posądzonych o zdradę i szpiegostwo na rzecz Rosji stracono na podstawie wyroków sądów polowych i drugie tyle bez sądów ${ }^{44}$. Tym razem Ukraińcy wzięli odwet na moskalofilach ${ }^{45}$. Ponownie tysiące osób internowano w obozie Thalerhoffie. Ale system którzy stworzyli wojskowi dotykał także inne grupy ludności. Opisując stosunki, jakie zapanowały Wincenty Witos stwierdzi „Tak władze cywilne jak i wojskowe, nie zajmując się wcale losem nieszczęśliwych ludzi, rozpoczęły formalne polowanie na zdrajców, którzy rzekomo winni byli wszystkich klęsk i nieszczęść. Za rzecz najpilniejszą uważano uruchomienie ogromnego aparatu szpiegowskiego,

${ }^{42}$ J. Hupka, Z czasów wielkiej wojny..., s. 185.

43 Uchwały zjazdu delegatów miast, Kraków 25 XI 1917, CDIAUL, f. 717, op. 1, spr. 31, s. 178a.

${ }^{44}$ Rzady wojskowych, „Piast” 1917, nr 52 z 30 grudnia, s. 2.

45 Raport nr 1 ob. H. Herziga z objazdu Galicji Wsch., Kołomyja 3 III 1916, ANKr, Arch. NKN t. 281, k. 83. 
którego zadaniem było tropienie każdego, kto «współdziałał z wrogiem». Na podstawie donosów - często najpodlejszą zemstą podyktowanych - zaczęto aresztować każdego, kto miał jakiekolwiek stosunki z władzami rosyjskimi. Włóczono gromady ludzi przed sądy wojskowe, skazywano na ciężkie i długoletnie więzienie, a nierzadko na karę śmierci. Nietrudno sobie wyobrazić, jak daleko w tych warunkach donosicielstwo, nie tylko zemstą osobistą podyktowane, ale bardzo często pieniędzmi rządowymi opłacane $^{46}$. Nie sposób podać dokładnej liczby ofiar represji austriackich w tym okresie. Poseł do parlamentu austriackiego Władysław Długosz szacował je dla całej Galicji na około 60 tysięcy osób ${ }^{47}$.

\section{Od aktu 5 listopada do pokoju brzeskiego}

Ostatnią próbą odbudowania autorytetu monarchii habsburskiej wśród Polaków było wydanie manifestu dwucesarskiego z 5 listopada 1916 zapowiadającego powstanie niepodległego państwa polskiego na ziemiach zaboru rosyjskiego. Wprawdzie stanowiła ona jednocześnie krech trialistycznych planów polityków Naczelnego Komitetu Polskiego ale ze względu na międzynarodowe reperkusje stanowiła krok w kierunku rozwiązania sprawy polskiej. Ze względu na zawód galicyjskich Polaków, oczekujących połączenia Królestwa Polskiego z Galicją towarzyszyła mu deklaracja Franciszka Józefa I o „wyodrębnieniu Galicji”

Wielu Polaków w Galicji odebrało akt 5 listopada entuzjastycznie, traktując go jako rzeczywiście początek niepodległości. Zofia Romanowiczówna tak opisze w dzienniku tę chwilę: „Pamiętam i nigdy nie zapomnę, jak już 3-go wieczorem na jakimś małym posiedzeniu naszym wszedł do Ligi [Kobiet] pan Tomicki i powiedział «Jutro będzie ogłoszony manifest cesarzy uznający Królestwo wolną i niepodległą Polską». Pani Mościcka stała najbliżej, rzuciłam się jej na piersi i płakałam z radości -o! takimi łzami nie płakałam jeszcze nigdy w życiu - taka chwila jest jedyną a wielkość jej równa chyba tylko chwilom mistycznego zachwytu. $\mathrm{Na}$ razie nie zdawałam sobie sprawy, z tego, że to dopiero część naszych pragnień i dążeń, że tyle Polski jeszcze zostaje w niewoli, a i ta wolność częściowa jeszcze nieurzeczywistniona... Chodziłam odtąd jak zaczarowana, jak w ciaggłej ekstazie" 48 . Naczelny Komitet Narodowy i jego terenowe struktury współorganizowały na terenie całej Galicji od 8 do 20 listopada

46 W. Witos, Moje wspomnienia..., s. 452-453.

47 Ein Reden der Abgeordnete Dtugosz, in In: Stenographisches Protokoll Haus der Abgeordneten XXII Session (30.05.1917-12.11.1918), 59. Sitzung, s. 3137.

48 Z. Romanowiczówna, Dziennik lwowski 1842-1930..., t. 2, s. 277. 
1916 roku szereg manifestacji z okazji wydania aktu 5 listopada. Odbyły się one we wszystkich miastach powiatowych oraz w wielu mniejszych ośrodkach Galicji. Szczególnie okazale wypadły demonstracje we Lwowie, Krakowie, Przemyślu, Tarnowie, Rzeszowie, Białej ${ }^{49}$. W tym czasie wydawało się wielu, że oto wracają chwile entuzjazmu pierwszych dni wojny, ale wkrótce okazało się że za szumnymi zapowiedziami nie idą fakty. Już wkrótce śmierć Franciszka Józefa I i rozpoczęcie panowania Karola I otworzyły nową erą w stosunkach Polaków z monarchią habsburską. Nowy cesarz ${ }^{50}$. nie cieszył się wśród nich taką estymą jak jego poprzednik. Sam Karol po objęciu tronu starał się nie manifestować swoich dotychczasowych sympatii politycznych ale zdymisjonowanie przez nowego władce premiera Ernsta Körbera, odpowiedzialnego za wykonanie projektu wyodrębnienia Galicji oznaczało, że monarchia przyjęła nowy kurs wobec swych galicyjskich poddanych.

Zmagania militarne wojsk austro-węgierskich i niemieckich $\mathrm{z}$ armią rosyjską były przyczyną dużych strat materialnych zarówno w miastach jak i na terenach wiejskich. W latach 1914-1915 działania wojenne objęły cały obszar Galicji, oprócz jej najbardziej na zachód ośmiu wysuniętych powiatów. Należy podkreślić, że na terenie Galicji Wschodniej toczyły się one znacznie dłużej, bo praktycznie do końca 1917 roku. Część zniszczeń i strat nie była przy tym wynikiem walk, lecz powstała z jednej strony w wyniku celowych działań wojsk austro-węgierskich w trakcie odwrotu w 1914 roku z drugiej zaś strony powstała w wyniku realizacji stosowanej od 1915 roku przez Rosjan taktyki pozostawiania za sobą „spalonej ziemi". Poza zniszczeniami wywołanymi w trakcie bezpośrednich działań militarnych, duże straty zostały poczynione przez ciągłe rekwizycje, których dokonywały oddziały wszystkich walczących armii, a także przez rabunki czynione przez zwykłych żołnierzy, maruderów i dezerterów. W niektórych powiatach część szkód spowodowali uciekający z terenów objętych walkami uchodźcy. Dokonywano również grabieży i zniszczenia mienia pozostawionego bez opieki przez uchodźców wojennych czy też ewakuowanych ${ }^{51}$. Istotny problem, coraz bardziej nasilający się od począt-

${ }^{49}$ Na temat manifestacji: L. Mroczka, Galicji rozstanie z Austria. Zarys monograficzny, Kraków 1990, s. 18-19; J. Z. Pająk, Od autonomii do niepodległości..., s. 178-187; J. Pajewski, Odbudowa państwa polskiego..., s. 105-117; Tarnów. Dzieje miasta i regionu, red. F. Kiryk, Z. Ruta, Tarnów 1983, cz.2, s. 221.

${ }^{50}$ Karol I jeszcze jako następca tronu, popierany był przez wyższy korpus wojskowy oraz polityków związanych z austr. Sztabem Generalnym, niechętnych polskim aspiracjom politycznym i wspierających projekt utworzenia odrębnego ukraińskiego kraju koronnego przez podział Galicji.

${ }^{51}$ Szerzej na ten temat T. Kargol, Odbudowa Galicji ze zniszczeń wojennych w latach 1914-1918, Kraków 2012. 
ku 1916 stanowił chroniczny brak rąk do pracy, wywołany z jednej strony przez pobór do armii prawie wszystkich mężczyzn, jak również celowe wyludnienie obszarów bezpośrednio przytykających do strefy frontowej.

Zniszczenia wojenne i skutki wprowadzonej przez władze c. k. monarchii gospodarki wojennej podcięły podstawy egzystencji szerokich grup społeczeństwa galicyjskiego, szczególnie we wschodniej części kraju. Według Edwarda Rose, podczas wojny światowej nastąpiło dramatyczne ograniczenie powierzchni ziem uprawnych na terenie byłej Galicji ${ }^{52}$. $\mathrm{W}$ rezultacie nastąpiło załamanie produkcji rolnej. Również rzemiosło i przemysł pozbawione $\mathrm{w}$ dużej mierze surowców musiały znacznie ograniczyć produkcję. Represje, szalejące sądy doraźne, rekwizycje środków żywności, powszechny brak artykułów pierwszej potrzeby - wszystko to rozwiewało resztki iluzji wobec monarchii. Ludność Galicji, wychowana w duchu lojalizmu, dochodziła swoich krzywd w drodze legalnej, poprzez składanie petycji i zażaleń do władz. Skarżono się w nich na postępowanie władz administracyjnych, na rekwizycje zboża, ziemniaków i inwentarza, drożyznę, spekulację, łapownictwo, oraz brak podstawowych towarów.

Szczególnego znaczenia w latach 1916-18 nabierała kwestia aprowizacyjna. Od pierwszej połowy 1916 roku rząd austro-węgierski został zmuszony do wprowadzenia systemu reglamentacji i centralnej redystrybucji środków żywności. Wprowadzany sukcesywnie system central wojennych przejął w praktyce cały obrót towarowy i wyeliminował możliwość zaopatrywania się u producentów czy to krajowych czy to zagranicznych $^{53}$. Bardzo szybko okazało się, że ten system dyskryminuje Galicję. Jak stwierdzała Zofia Daszyńska-Golińska, „Galicja jako, kraj rolniczy uznaną została za człon państwa przeznaczony do wywozu produktów spożywczych, natomiast ze względu na niskie potrzeby swej ludności stale była i jest pomijaną w przydziale tych artykułów, które się dowozi z neutralnej zagranicy. Tymczasem Galicja ze swoją bardzo gęstą ludnością i niższy$\mathrm{mi}$, niż w innych krajach austriackich plonami w czasach przedwojennych

52 E. Rose, Bilans gospodarczy trzech lat niepodległości, Warszawa 1922, s. 19.

${ }^{53}$ Jak pisał działacz Książęco-Biskupiego Komitetu w wyniku tych posunięć: „,w jawnym handlu hurtowym znikły wszelkie towary - natomiast pojawiły się w wielkich ilościach w handlu pokątnym, oczywiście po cenach niezmiernie wysokich. Tu i ówdzie można było jeszcze nabyć towary z dawniejszych zapasów u firm solidnych, gdy jednak i te wyczerpały się, byliśmy skazani na pokonanie przeróżnych trudności, by ludność zaopatrzyć w najniezbędniejsze artykuły, zwłaszcza, że mimo ciągłych starań nie mogliśmy uzyskać u central wiedeńskich przydziału towarów i należytego ocenienia naszej działalności, jakkolwiek szła ona w parze z państwową akcją zwalczania lichwy żywnościowej". Sprawozdanie z działalności Lwowskiej Delegacji KBK za czas od 5 VIII 1915 do 31 XII 1917, [w:] Trzy lata działalności K. B. K. Sprawozdanie Książęco Biskupiego Komitetu Pomocy dla Dotkniętych Klęska Wojny za lata 1915-1917, Kraków 1917, s. 373. 
nigdy zbożem własnym obdzielić nie mogła swoich mieszkańców. Dziś po 3 latach inwazji, po oderwaniu od pracy rolnej prawie całej dorosłej męskiej ludności w wieku produktywnym (pozostali starcy, dzieci, i kobiety), kiedy na wschodzie kraju jakieś $40 \%$ obszaru nie zostało uprawione, nie może absolutnie wystarczyć dla ludności własnej nawet. Dodajmy do tego rekwizycje dla wojska austriackiego i trwające całe miesiące postoje setek tysięcy, a może i miliona żołnierzy armii niemieckiej, weźmy pod uwagę wysyłanie całych pociągów prowiantu do Niemiec, o których wieści przedostają się coraz częściej, a zrozumiemy, że źle być musi i że każda rodzina indywidualnie wszelkimi przysługującymi jej sposobami broni się przed głodem. Co do produktów, które z zewnątrz dostarczane być musza, to ceny są tu fantastyczne lub zupełny brak, bo panuje gospodarka znienawidzonych dziś powszechnie central" ${ }^{\prime 54}$.

W prowincji szalała drożyna i brakowało wielu podstawowych artykułów, wraz z wprowadzeniem reglamentacji i cen maksymalnych pojawił się czarny rynek. W Krakowie czarnorynkowe ceny artykułów były wyższe od oficjalnych do 1916 około dwukrotnie, by w drugim okresie wojny wzrosnąć do poziomu 500\%. Pogarszało to nastroje społeczne. Od jesieni 1916 braki aprowizacyjne były już tak ogromne, że głodowały nie tylko miasta, ale także obszary rolnicze, szczególnie we wschodniej Galicji i na terenach podgórskich. Nieudolna i pozbawiona faktycznej możliwości działania cywilna administracja austriacka zupełnie sobie $\mathrm{z}$ tym problemem nie radziła. $W$ rezultacie $\mathrm{w}$ 1. 1917-18 systematycznie dochodziło w miastach Galicji do rozruchów głodowych, czasami połączonych z ekscesami antyżydowskimi ${ }^{55}$.

Duży wpływ zarówno na przebieg wojny jak i dla sprawy polskiej miał wybuch rewolucji rosyjskiej w lutym 1917 roku. Deklaracje utworzonych wówczas w Rosji ośrodków władzy popierały ideę utworzenia państwa polskiego. Uznając prawo Polski do własnego państwa Rosja pozwalała tym samym swoim sojusznikom na zajęcie stanowiska w sprawie polskiej. W tym samym czasie Karol I odstąpił w praktyce od „wyodrębnienia" Galicji. Wszystko to powodowało weryfikację stosunku Polaków w Galicji do monarchii habsburskiej. Gdy więc cesarz zwołał w maju 1917 parlament austriacki członkowie Koła Polskiego przyjęli deklarację stwierdzająca, że jedynym celem Polaków w tej wojnie jest odbudowanie niepodległej Polski z dostępem do morza. Nie stało to formalnie w sprzeczności z lojalnością wobec Austro-Węgier, gdyż jak podkreślano miało się to stać $w$ ramach rozwiązania austro-polskiego. Ta deklaracja

54 Z. Daszyńska-Golińska, W trudnej chwili, „Na Posterunku”, 1917, nr 50 z 9 grudnia, s. 2-3.

55 Szerzej na ten temat: J. Z. Pająk, Od autonomii do niepodległości..., s. 177-178, 238-244. 
- przyjęta pod naciskiem ulicy, przy sprzeciwie konserwatystów i demokratów - odzwierciedlała nową optykę liderów socjalistów, ludowców i narodowych demokratów którzy stawali się w tym czasie wyrazicielami opinii społeczeństwa polskiego.

W początkach 1918 doszło do otwartego buntu Polaków wobec Austro-Węgier. Przyczyną było podpisanie przez państwa centralne traktatu pokojowego z Rosją i nowo powstającą Ukrainą. Polacy którzy nie zostali dopuszczeni do negocjacji pokojowych już od styczna 1918 roku organizowali na terenie Galicji szereg demonstracji na których sprzeciwiano się planom oddania wschodniej części Galicji państwu ukraińskiego ${ }^{56}$. Gdy do podpisania układu pokojowego doszło, a wśród jego zapisów znalazły się również i te które oddawały Chełmszczyznę i Podlasie Ukrainie polska opinia publiczna przyjęła to jako jawną zdradę Habsburgów, akt gwałtu i kolejny rozbiór Polski. Choć zawarcie pokoju brzeskiego było w istocie mało znaczącym epizodem I wojny światowej to w społeczeństwie polskim i ukraińskim odbiło się głośnym echem. Oderwanie Chełmszczyny od Królestwa, dodajmy nigdy w praktyce niezrealizowane miało jednak znaczenie symboliczne zarówno dla jednej jak i drugiej strony. Dla Polaków oznaczało, że ani Niemcy ani też Austro-Węgry nie liczą się z polskimi dążeniami narodowymi, że związanie z tymi państwami losów Polskich może przynieść tylko katastrofę narodową. W tym sensie Brześć stanowił kres praktycznego działania polskich zwolenników rozwiązania trialistycznego. Okazywało się, że wszelkie rachuby i plany snute na bazie przyszłego związku ziem polskich z monarchią habsburską ostatecznie legły w gruzach.

Wywołało to niespotykaną przed tem falę manifestacji i zamieszek Były to najbardziej masowe i najbardziej zdecydowane wystąpienia ludności polskiej w zaborze austriackim od początku wojny. Zaprotestowały także reprezentacje polityczne Polaków w Austrii: przede wszystkim Koło Polskie w parlamencie austriackim ${ }^{57}$, Koło Sejmowe w Sejmie Krajowym oraz polscy członkowie Izby Panów w Wiedniu ${ }^{58}$. W akcie protestu Polski Korpus Posiłkowy pod dowództwem Józefa Hallera przedarł się przez front pod Rarańczą na Bukowinie. Pozostałych legionistów rozbrojono i internowano na Węgrzech ${ }^{59}$. Przebieg i charakter protestów zależał w dużej mierze od siły żywiołu polskiego w poszczególnych częściach Galicji. Od 11 lutego 1918 manifestowali zwolennicy wszystkich polskich kierunków

\footnotetext{
56 Ibidem, s. 203-205.

57 Odezwa Koła Polskiego, „Czas”1918, nr 80, z 19 lutego, s. 1.

58 Oświadczenie polskich członków Izby Panów, „Czas” 1918, nr 80, z 19 lutego, s. 1.

59 Szerzej J. Snopko, Finał epopei Legionów Polskich, Białystok 2008, passim, S. Czerep, II Brygada Legionów Polskich, Warszawa 1991, s. 198-207.
} 
politycznych, jednak najbardziej aktywni byli socjaliści, narodowi demokraci i ludowcy. Protestowali także polscy wychodźcy w krajach monarchii austriackiej, m.in. w Wiedniu, Pradze, Opawiea także Polacy na Śląsku Cieszyńskim m.in. w Cieszynie, Polskiej Ostrawie i Karwinie. Najbardziej masowe i zdecydowane wystąpienia miały miejsce głównie na terenie zachodniej i środkowej Galicji oraz w dużych ośrodkach miejskich w Krakowie, Lwowie, Tarnowie, Rzeszowie, Stanisławowie, Białej i Przemyślu. Apogeum protestów przypadło na 18 lutego, gdy przeprowadzono w Galicji ośmiogodzinny strajk generalny, połączony z kolejnymi burzliwymi manifestacjami. Brali w nich udział także urzędnicy państwowi i samorządowi, sędziowie, nauczyciele oraz duchowni. Z budynków zrywano austriackie szyldy i godła państwowe. W większości ośrodków, łącznie ze Lwowem i Krakowem porządku pilnowały straże obywatelskie, gdyż policja austriacka nie była tego w stanie go zapewnićc0. Można stwierdzić, że w lutym 1918 polska część społeczeństwa Galicji symbolicznie zrywała z monarchią habsburską.

\section{Koniec rządów austriackich w Galicji}

Zakwestionowany w trakcie manifestacji lutowych autorytet państwa austro-węgierskiego nie dał się już odbudować. Toczący się w MarmarosSziget proces przeciwko internowanym żołnierzom PKP, o którym relacje zamieszczała cała codzienna prasa polska przypominał o tym fakcie. Zainteresowanie ich losem, było w społeczeństwie polskim ogromne. Podejmowano szereg działań, aby im ułatwić egzystencję. Organizacje takie jak Liga Kobiet organizowały zbiórki na ich rzecz. Wiele osób starało się ich odwiedzić. Posłowie do parlamentu, m.in. Ignacy Daszyński wnosili interpelacje do rządu w ich sprawie. Po umorzeniu procesu w październiku 1918 i powrocie internowanych żołnierzy polskich organizowano na ich cześć manifestacje, wydawano także uroczyste kolacje i obiady, w trakcie których otwarcie mówiono o konieczności zerwania ze „zdradziecką” Austrią.

Jedną z widocznych odznak rozpadu państwa i armii austriackiej stały się począwszy od późnego lata masowe dezercje żołnierzy. Posterunki żandarmerii donosiły w całej Galicji o grupach dezerterów ukrywających się po lasach i bardziej niedostępnych osiedlach szczególnie w Karpatach. Wielu z tych dezerterów, pochodzących z Galicji, uciekało w ro-

${ }^{60}$ Najszersza w literaturze dokumentacja dot. protestów brzeskich w Galicji - J. Z. Pająk, Od autonomii do niepodległości..., s. 205-227, oraz Aneks nr 6, s. 293-340, zob. także L. Mroczka, Galicji rozstanie z Austria..., s. 221-246. 
dzinne strony i tam korzystając z pomocy rodziny starali się ukryć przed żandarmami. W późnych miesiącach jesiennych wobec słabości aparatu policyjnego bandy dezerterów terroryzowały całe powiaty ${ }^{61}$. Jak 18 października 1918 r. donosił starosta tarnowski, rosła przestępczość i bandy uzbrojonych dezerterów z którymi żandarmeria nie mogła sobie poradzić. Ludność zaś nie wydawała władzom ich kryjówek. Organy państwa pozostawały bezsilne, zaś autorytet państwa w oczach jego formalnych obywateli ulegał przez to dalszemu obniżeniu ${ }^{62}$.

Od września 1918 r. wraz z informacjami o klęskach niemieckich na froncie zachodnim narastał zamęt i chaos. Powszechnie bojkotowano decyzje władz, które nie były w stanie wymusić elementarnego posłuszeństwa. Z urzędów zrywano austriackie godła i szyldy. Przy biernej postawie eskortujących je żołnierzy przeszukiwano transporty wojskowe, uniemożliwiając wywóz z prowincji żywność i innych deficytowych artykułów. Jednocześnie przez prowincję przetaczały się nieustanne manifestacje i demonstracje, na których zarówno Polacy jak i Ukraińcy domagali się własnego państwa. Ujawniła się też radykalizacja nastrojów społecznych wśród chłopów i robotników. W takich warunkach doszło do ostatecznego upadku panowania Habsburgów w Galicji i przejęcia władzy przez Polską Komisję Likwidacyjną ${ }^{63}$.

\section{Zakończenie}

Okres I wojny światowej stanowił ostatni okres przynależności Galicji do wielonarodowego i wielowyznaniowego państwa austro-węgierskiego. Podczas Wielkiej Wojny trwał proces dekompozycji i rozpadu podstaw budowanego ponad sto lat panowania Habsburgów nad tą częścią Europy Środkowej. System dotychczasowych rządów rozpadł się w ciągu pierwszego roku wojny, gdy w wyniku klęsk wojennych armia i administracja austriacka musiały się wycofać z Galicji. Po powrocie panowania austriackiego, mimo odbudowy i rekonstrukcji administracji, nie odzyskała ona, dawnego autorytetu wśród rządzonych. Zasadniczą tego przyczyną było

${ }^{61}$ Szerzej na ten temat J. Z. Pająk, Od autonomii do niepodległości..., s. 247-248.

${ }^{62}$ Narodziny niepodległości w Galicji (1918-1919). Wybór tekstów z archiwów lwowskich, opr. Marek Przeniosło, Kielce 2007, s. 134-135. Podobnie uważał starosta w Strzyżowie L:224/pr. Pismo Starosty w Strzyżowie do Namiestnictwa w sprawie dezerterów wojskowych, Strzyżów 19 X 1918, CDIAUL, f. 146, op.4, spr. 7166, s. 125 Podobnie oceniał sytuację ówczesną Jędrzej Moraczewski, zob. Przewrót w Polsce, cz.1, Rządy ludowe. Szkic wypadków czasów wyzwolenia Polski do 16 stycznia 1919 roku. Warszawa-Kraków 1919, s. 10.

63 Szerzej M. Przeniosło, Polska Komisja Likwidacyjna 1918-1919, Kielce 2010, 
podporządkowanie jej Naczelnej Komendzie Armii i polityce przez nią prowadzoną. Inną równie istotną był widoczną i postępująca degeneracja struktur państwa austro-węgierskiego i ich rosnące uzależnienie od potężnego i niechętnego Polakom sojusznika - II Rzeszy Niemieckiej. Słabość i niewielkie $\mathrm{w}$ istocie możliwości działania aparatu urzędniczego Galicji wyszły szczególnie jaskrawo na jaw, gdy jej przedstawiciele nie byli w stanie przywołać do porządku działających poza prawem żołnierzy i oficerów własnej, a także sojuszniczej armii niemieckiej. W ostatnich latach wojny narastający problem aprowizacyjny i kłopoty w zakresie odbudowy kraju, stały problem uchodźców wojennych był dla administracji Galicji w istocie nie do rozwiązania. Szczególnie aprowizacja była czynnikiem stale generującym niezadowolenie ludności. Ta niemożność rozwiązywania podstawowych problemów społeczeństwa pogłębiała się w miarę trwania wojny, budząc na początku irytację, następnie niechęć a potem nienawiść do nieudolnej administracji zaborczej. Te doświadczenia rozwiewały mit o „dobrym” cesarzu i uzmysławiały dobitnie mieszkańcom Galicji obcość zaborczej władzy i administracji stwarzając zarazem podatny grunt dla zaakceptowania idei własnego państwa, które broniłoby interesów własnych obywateli.

\section{Zusammenfassung}

\section{POLEN IN GALIZIEN GEGENÜBER ÖSTERREICH-UNGARN IN DER ZEIT DES ERSTEN WELTKRIEGES}

Der Prozess der Bildung des Nationalbewusstseins bei den in Galizien lebenden Polen war ziemlich einzigartig, was von der Zugehörigkeit zu einem multinationalen und multireligiösen Habsburger Reich kam. Im Laufe von einer über ein Jahrhundert langen Geschichte des österreichischen Teilungsgebiets hat sich da, insbesondere in der autonomen Periode, eine Art von Politiker und Aktivisten entwickelt, die ihr eigenes Gefühl des nationalen Patriotismus mit einem bestimmten österreichisch-ungarischen Patriotismus verbunden haben. Die Hauptgruppen der Bevölkerung akzeptierten das bestehende Regierungssystem und damit auch die Zugehörigkeit zur österreichisch-ungarischen Monarchie. Dazu trugen die relativ höheren, als in den anderen Gebieten Polens, politischen Freiheiten bei, insbesondere die Entwicklung des Parlamentarismus. Während des Großen Krieges entwickelte sich der Prozess der Zersetzung und des Zerfalls von Grundlagen der seit über hundert Jahren gebauten habsburgischen Herrschaft über diesen Teil Mitteleuropas. Die bisherigen Regierungen brachen während des ersten Kriegsjahres zusammen, als infolge der Kriegskatastrophe die österreichische Armee und Verwaltung aus Galizien zurücktreten mussten. Nach der Rückkehr der österreichischen Herrschaft, trotz der Sanierung und des Umbaus der Verwaltung, hat sie ihre ehemalige Autorität nicht mehr zurückgewonnen. Die Hauptursache war eine fortschreitende Degeneration der Strukturen des österreichisch-ungarischen Staates und seine zunehmende Abhängigkeit von dem 
mächtigen und den Polen gegenüber negativ eingestellten Verbündeten - dem Zweiten Deutschen Reich. In den letzten Jahren des Krieges waren das wachsende Verpflegungsproblem und Schwierigkeiten beim Wiederaufbau des Landes sowie ein ständiges Problem der Kriegsflüchtlinge für die Verwaltung von Galizien im Grunde genommen unlösbar. Diese Unfähigkeit, grundlegende Probleme in der Gesellschaft zu lösen, hat sich während des fortschreitenden Krieges vertieft, was anfangs Verärgerung, dann Abneigung und zum Schluss auch Hass gegen die unfähige Verwaltung der Besatzungsmächte auslöste. Diese Erfahrungen haben den Mythos von dem „guten“ Kaiser ausgeräumt und den Menschen in Galizien deutlich die Entfremdung der Behörden und Verwaltung von Teilungsmächten bewusst gemacht, wobei sie in der gleichen Zeit einen fruchtbaren Boden für die Annahme der Idee des eigenen Staates schufen, der die Interessen der eigenen Bürger schützen sollte. 